\title{
Annual runoff coefficient in the Cerhovický Stream catchment
}

\author{
Martina Vlčková, Marek Nechvátal, Mojmír Soukup
}

Research Institute for Soil and Water Conservation, v.v.i., Žabovřeská 250, 15627 Praha 5 Zbraslav, Czech Republic, e-mail: vlckova@vumop.cz

\begin{abstract}
The runoff coefficient is one of the fundamental hydrological characteristics of a catchment. It indicates a share of the precipitation water that runs off from the catchment.

The results of the runoff coefficient calculation based on measurements carried out continuously in the Cerhovický Stream catchment over a considerable period of time, i.e. from 1988 up to 2006 are presented. The precipitation and runoff data in the catchment were used.

Mean value of the runoff coefficient and the runoff coefficients for the agricultural and forest parts of the catchment are presented. The total mean runoff coefficient for the Cerhovický Stream is 0.19 with the standard deviation of 0.06 . Mean runoff coefficient for the forest part is 0.13 and for the agricultural part -0.24 .

Differences between the years with a higher and a lower precipitation were followed as well. We also statistically evaluated possible hydrological changes caused by the construction of the highway and the market centre. For another possible explanation of quite high standard deviation of the mean annual runoff coefficient we followed the monthly runoff coefficient dependence on water temperature and of ground water table depth.
\end{abstract}

Key words: runoff coefficient, dry year, wet year, land use, water temperature, ground water level

\section{INTRODUCTION}

The runoff coefficient is one of the fundamental hydrological characteristics of a catchment. It defines the share of precipitation that leaves the defined area during specific time period as an outflow. In any water management operation the runoff plays a significant role as an input variable in the design of engineering structures such as culverts, reservoirs, in groundwater recharge estimation, and in flood control. The runoff coefficient plays a central role in the calculations of the surface water yield of a catchment due to many forms of precipitation. It is quantitatively related to various interrelated factors such as (DOLEŽAL et al., 2006; DOSTÁL, 2002; JANEČEK, 2002; KADIOGLU and ŞEN, 2001; MAIDMENT, 1993; RATZLAFF, 1994; SOUKUP, 2000; ŚVIHLA, 1979): 
- shape of the catchment (delta shape, or short and narrow),

- hydrological conditions - physical properties of the soil,

- vegetation cover (land use),

- roughness (runoff velocity),

- leaf covered area (interception),

- protection of the original earth surface by tree roots and leafs,

- the climate (precipitation and temperatures),

- character of the riverbed,

- directional lead (the length) - > slope,

- river bed and shore type (roughness, stability),

- field drainage,

- the amount and intensity of precipitation and evaporation,

- the spatial arrangement and utilisation of the catchment,

- human activity (agricultural and building),

- the degree of ground saturation.

An important factor for the runoff formation is the degree of soil saturation which accompanies heavy rains. During the saturation of the ground by rain water (attaining the full soil potential for water retention and accumulation) the runoff coefficient, which is close to 0.8 to 0.9 rises significantly. It means that 80 to $90 \%$ of the precipitation volume in the affected region flows out of the area. This situation occurs after extreme rainfalls and under flood conditions.

Among the factors affecting total runoff the controlled drainage - part of the hydrological balance of the drained, agriculturally utilised catchment area - should be mentioned. Under certain conditions the controlled drainage can be used, for example through biotechnical measures and during the drainage systems' reconstruction. Long term monitoring of the drainage runoffs in experimental catchments shows that instant maximum drainage within small groups does exceed the usual, specifically planned drainage by roughly 4.5 to 5 times. On the other hand, the highest possible contribution of field drainage to the flood runoffs is restricted by the hydraulics of water movement within the ground and by the hydraulics of the pipe draining itself (SOUKUP et al., 2003). Drainage of the land lowers the underground water table depth (UWT) by approx. 0.2 to $0.3 \mathrm{~m}$. It adjusts the moisture conditions for cultivated crops and frees up a retention space which may minimise the risk of high runoff during extreme precipitation (MAXOVÁ and SOUKUP, 2004). Within the Czech territory, a total of 108700 hectares (approximately $25 \%$ of agricultural lands) has been drained over time.

The runoff coefficient for various time periods may be determined subsequently and in many contexts concerning hydrological characteristics. The value of the mean annual runoff coefficient does not allow a comparison of individual runoff episodes; it is, however, suitable for long range predictions and monitoring in broader climatic context. SAVENIJE (1995) used a mean annual runoff coefficient to 
follow up the relations between the runoff coefficient and recirculation of precipitated moisture. He confirmed the fact that the influence of evapotranspiration by plants is likely the most important mechanism for retaining the precipitation within the continental watershed. BARANKIENE (2002) found very close relationship between precipitation and runoff during a long-term (62-72 years) data analysis. A cyclic (15 years) occurrence of wet and dry periods in the Susve basin, similar to the occurrence of runoff was found.

Global Runoff Data Centre (GRDC) presents long-term mean annual runoff coefficients for all above sea levels on every continent. According to their report, in the global scale the outflow coefficient could be 28 to $39 \%$. The maximum yearly values for the Czech Republic exceeding the average runoff coefficient by $50 \%$ are found in Moravia/Silesian Beskydy Mountain Range (Morávka 59\%, Ostravice 55\%), along the upper Moldau River (56\%), and in Labe on Hostinné (54\%). During flood periods the runoff coefficient can reach 0.8-0.9. The lowest values are found along the tributaries of the Elbe and the lower Moldau River, where the runoff coefficient reaches 10 to $15 \%$. Among the larger rivers the low runoff coefficient is found in the Dyje outflow (at its Morava River estuary - 18\% and above Novomlýn Water Reservoirs - 14\%) (Voda...: http://www.zemepis. com/vodacr.php)

VÚMOP evaluated the runoff coefficient for the Cidlina River. Soukup (1987) estimated the mean annual runoff coefficient for the Cidlina River during moist years at 0.496 and for dry years at 0.342 . Soukup, using 39-year records from the Cidlina River expressed the relationship between the runoffs and precipitation with a linear equation with the regression coefficient of 0.604 .

\section{MATERIALS AND METHODS}

\section{THE EXPERIMENTAL CATCHMENT}

The study area was situated in the upper part of the Cerhovice Stream catchment in Beroun County (ŠVIHLA, 1979). The area was established for the purpose of evaluating the functions of drainage systems and their effect on hydro-economic situation (SOUKUP and NECHVÁTAL, 2006).

The experimental catchment is part of the Hořovice Uplands (Fig. 1). The geological substratum is composed of layered slate from the earlier Palaeozoic Era. The ground consists of clay-loam to loam-clay soil, which is not very permeable. The soil's porosity ranges from $41 \%$ to $45 \%$. The normal precipitation at Jince station from 1901 to 1950 was $558 \mathrm{~mm}$. The mean annual temperature is $7.5^{\circ} \mathrm{C}$ (SOUKUP et al., 2004).

The long term monitoring of precipitation, surface and drainage runoff, as well as the records of agricultural economics have been carried out within this 


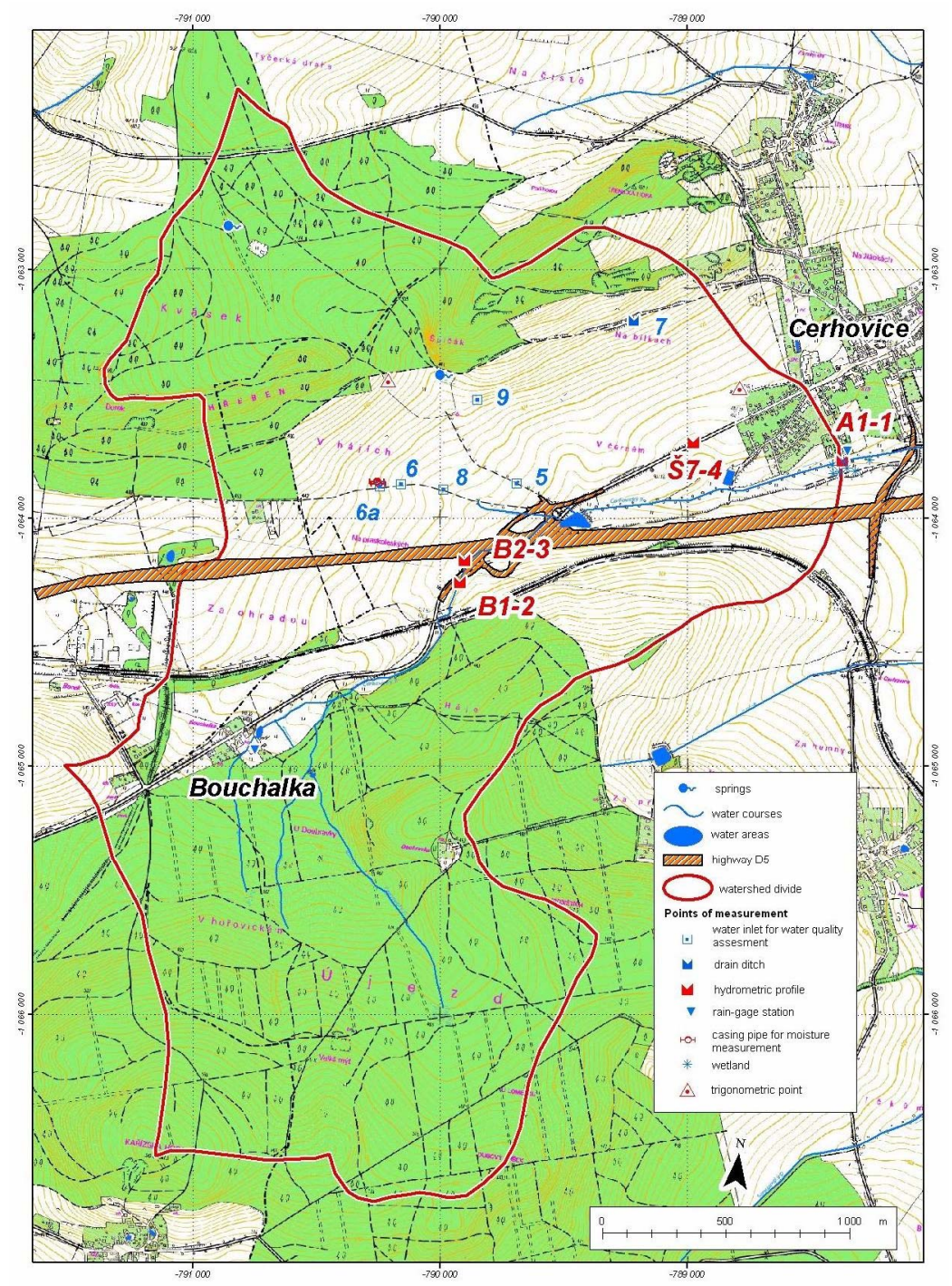

Fig. 1. The map of experimental Cerhovický Stream catchment, A, B, S-monitoring sites

catchment area (Tab. 1). Some of the agricultural lands $(16.4 \%$ of the catchment area) were drained during the 1970's. The spacing of drains varies from 9 to $18 \mathrm{~m}$; the depth of drains is 0.7 to $0.9 \mathrm{~m}$.

The highway D5 parallel with the axis of the stream bed connecting Prague's agglomeration with West Bohemian Plzen Metropolis and Germany was built during 1994 and 1995. Even though changes in the land use due to economic development following the year 1989 had occurred earlier, more significant changes took place later as a result of the secondary influence of the new highway. These 
Table 1. Basic characteristics of the experimental catchment (Soukup and NeChVÁtal, 2006; DOLEŽAL, 2002)

\begin{tabular}{ll}
\hline Hydrological sequence and the name & $1-11-04-034$ \\
of the experimental catchment & Cerhovice Stream \\
The longitude and latitude & $49^{\circ} 51^{\prime} \mathrm{N}, 13^{\circ} 50^{\prime} \mathrm{E}$ \\
Elevation above sea level & $390-572 \mathrm{~m}$ a.s.1. \\
Arable lands, \% & $18 \%$ \\
Meadows and pastures, \% & $22 \%$ \\
Forests, \% & $61 \%$ \\
Mean annual precipitation, mm, at Jince/Zbiroh station (1901-1950) & $558 / 617$ \\
Mean temperature, ${ }^{\circ} \mathrm{C}$, at Jince station/period (1901-1950) & 7.5 \\
Drainage by parallel drains, ha & 121.0 \\
Other kinds of drainage, ha & 15 \\
Monitoring time & $1988-2006$ \\
Substratum & Weathered crystalline shale \\
\hline
\end{tabular}

changes pertain mainly to the hydrological systems of the farmland and the countryside, and in such a way that forests remained untouched. Due to the highway construction, the end measuring profile $\mathrm{A} 1$ has been relocated by $1 \mathrm{~km}$ upstream to be above the outflows from the community. The monitoring object B1 at which the runoff from the forested catchment area is measured has been slightly moved as well (SOUKUP and NeCHVÁTAL, 2006). The runoff data collection at profiles A1 and B1 in 1995 and 1996 were interrupted for some time.

In 2002 a market centre was built in the upper part of the Cerhovice catchment. The project was completed in 2003. This particular structural object displaced circa 5 hectares of drained lands out of the agricultural use.

Table 2. The altitude of the monitoring station and the area of catchments

\begin{tabular}{lcl}
\hline \multicolumn{1}{c|}{ Monitored station } & Altitude, $\mathrm{m}$ a.s.l. & \multicolumn{1}{c}{ Area, $\mathrm{km}^{2}$} \\
\hline Profile A1 & 390.50 & 7.36 (before $1995-8.76 \mathrm{~km}^{2}$ ) \\
Profile B1 & 411.80 & 0.41 \\
Profile S7 & 403.43 & 3.32 \\
\hline
\end{tabular}

\section{MEASUREMENT OF THE CLIMATIC AND HYDROLOGICAL DATA}

Precipitation was measured at the monitoring station VÚMOP located near the profile A1. We kept the originally attained measurements at profile A1. We used some data for estimating the precipitation using correction coefficient for B1 or S7 profiles (DOLEŽAL, 2002). The correction coefficient for the Cerhovice Stream catchment was $X=0.32$. We used this value and entered it into the formula as follows: 


$$
\frac{P-P_{0}}{h-h_{0}}=X \quad \mathrm{~mm} \cdot \mathrm{year}^{-1} \cdot \mathrm{m}^{-1}
$$

where:

$P$ - annual total precipitation, valid for a chosen locality B1 and S7,

$P_{0}$ - annual total precipitation measured at a climatic station (monitoring station),

$h$ - altitude at the monitoring point in the catchment, $\mathrm{m}$;

$h_{0}$ - altitude of the climatic station, respectively precipitation measuring station, $\mathrm{m}$.

In all cases we used the precipitation values obtained within a hydrological year (XI-X).

During 1988-1994 and 1997-2006 the water flow was measured with flow meter at the base measuring profiles A1, B1 and S7. A1 was the end profile located on farmland; profile B1 was on the forested land and S7 was the profile of the drainage outlet, at which the monitoring ended in 2004 due to the construction of the supermarket.

\section{CALCULATION OF THE MEAN ANNUAL RUNOFF COEFFICIENT}

The yearly runoff coefficient for individual hydrologic years 1998 - 2006 was calculated according to the formula (HRÁDEK and KUŘíK, 2004; SOUKUP, 1987):

$$
\varphi=\frac{Q}{P}
$$

where:

$\varphi$ - yearly runoff coefficient,

$Q$ - the height of the mean annual runoff in $\mathrm{mm}$,

$P$ - the sum of annual precipitation in $\mathrm{mm}$.

The runoff coefficient was calculated for individual parts of the monitored area: for farmland section (A1-B1), for the forested section (profile B1), drainage area (profile S7) and finally for the whole catchment - profile A1.

\section{STATISTICAL ANALYSIS}

To evaluate the changes in hydrologic characteristics of the catchment connected with the changes of development we used statistic methods: $F$-test for com- 
parison of variances of two normal distributions and double-selection unpaired $t$-test for comparison of the means of two normal distributions along the same variations. We also estimated standard deviation for runoff coefficients from selected time periods before and after the highway construction and before and after the warehouse construction. We also compared the dry and wet periods.

\section{RESULTS AND DISCUSSION}

The total precipitation and runoff coefficients for given years are given in Fig. 2. We have kept together the values for the time period prior to construction, and for the period after the construction of the highway.

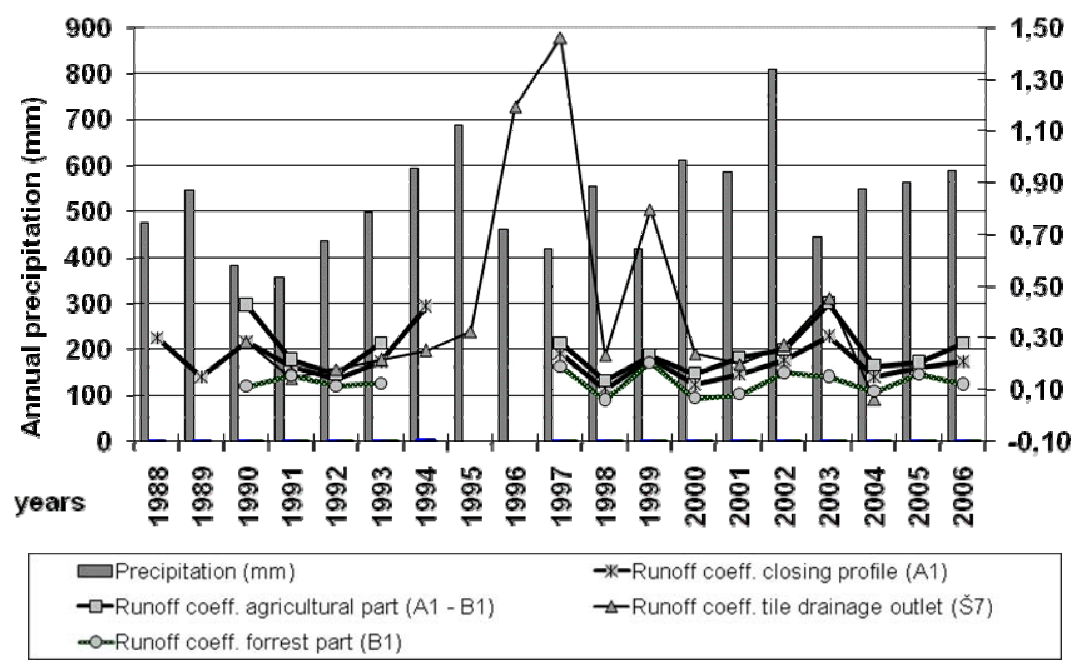

Fig. 2. Runoff coefficient and precipitation at the Cerhovice stream (1988-2006)

Calculated values of mean annual runoff coefficients for particular catchment sections during the mentioned time periods are given in Table 3. The values were calculated for the period before (1990-1993) and after highway construction.

Statistical evaluation of the mentioned values given below was made following KÁBA and SVATOŠOVÁ (1988). For values $m$ and $n$ we used the number of years in the compared time periods.

The runoff coefficients for the drier and the wetter years are compared in Table 5. Considering the short time we did not compare the sums of precipitation with their long-term average - $558 \mathrm{~mm}$ (as per 50 year time span ČHMÚ 1901$-1950)$. 
Table 3. Mean runoff coefficients for individual time periods

\begin{tabular}{l|c|c|c}
\hline \multicolumn{1}{c|}{ Monitoring stations } & $\begin{array}{c}\text { Mean runoff } \\
\text { coefficient }\end{array}$ & $\begin{array}{c}\text { Mean } \\
\text { precipitation } \\
\text { mm }\end{array}$ & $\begin{array}{c}\text { Standard deviation of runoff } \\
\text { coefficient (KÁBA and } \\
\text { SvATOŠOvÁ, 1988) }\end{array}$ \\
\hline Forested lands - B1 (1990-1993) & 0.125 & 425.07 & 0.02 \\
Forested lands - B1 (1997-2006) & 0.13 & 561.84 & 0.05 \\
Agricultural lands A1-B1 (1990-1993) & 0.27 & 418.30 & 0.12 \\
Agricultural lands A1-B1 (1997-2006) & 0.24 & 555.00 & 0.08 \\
Drained part - profile S7 (1990-1996) & 0.37 & 492.35 & 0.37 \\
Drained part - profile S7 (1997-2004) & 0.46 & 553.62 & 0.46 \\
Entire area - profile A1 (1988-1994) & 0.24 & 470.13 & 0.10 \\
Entire area - profile A1 (1997-2006) & $\mathbf{0 . 1 9}$ & 555.00 & 0.06 \\
Entire area of the end profile A1 prior & 0.18 & 566.90 & 0.06 \\
to market construction (1997-2002) & & & 0.07 \\
Entire area of the end profile A1 after & 0.21 & 537.30 & \\
market construction (2003-2006) & & & \\
\hline
\end{tabular}

The mean runoff coefficient for the Cerhovice Stream catchment was 0.19.

Table 4. Statistical evaluation of variances of the mean annual runoff coefficients for two different time periods $-F$-test

\begin{tabular}{l|c|c|c}
\hline \multicolumn{1}{c|}{$\begin{array}{c}\text { Variances of the mean annual } \\
\text { runoff coefficients for profiles }\end{array}$} & $\begin{array}{c}\text { Calculated } \\
F \text { value }\end{array}$ & $\begin{array}{c}\text { Critical value of } \\
\text { the test criterion } \\
F_{\alpha}(m-1, n-1) \\
\text { for } \alpha=0.05\end{array}$ & $\begin{array}{c}\text { Critical value of } \\
\text { the test criterion } \\
\mathrm{F}_{\alpha / 2}(m-1, n-1) \\
\text { for } \alpha=0.05\end{array}$ \\
\hline A1 before/after highway construction & 2.732 & 3.370 & 4.320 \\
B1 before/after highway construction & 6.725 & 8.812 & 8.905 \\
A1-B1 before/after highway construction & 1.934 & 3.860 & 5.078 \\
S7 before/after highway construction & 1.550 & 4.207 & 5.695 \\
A1 before/after warehouse construction & 1.403 & 4.347 & 7.764 \\
A1 dry years before/after highway construction & 2.679 & 9.277 & 15.439 \\
A1 wet years before/after highway construction & 7.297 & 9.277 & 15.439 \\
A1 dry/wet years prior the highway construction & 3.765 & 9.277 & 15.439 \\
A1 dry/wet years after the highway construction & 1.382 & 9.277 & 15.439 \\
\hline
\end{tabular}

Calculated results of mean runoff coefficients for individual catchment sections are illustrated in Fig. 2. The data cover the period 1996 to 2006 due to the highway construction (1995-1996), for the catchment part S7 - until 2004 (building-up of the warehouse).

Figure 4 show's precipitation - runoff relationship in the years after the highway construction. For a more detailed description of the ratio measure between the precipitation and runoff we chose the rising order of annual sums of precipitation. 


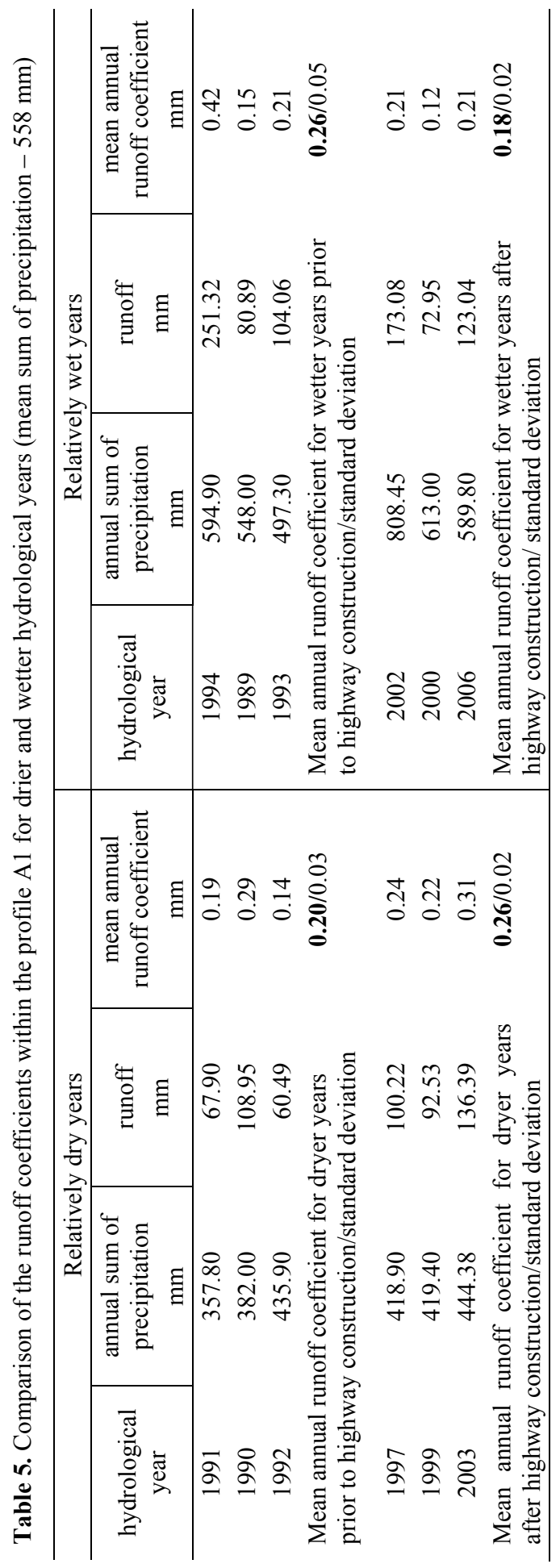




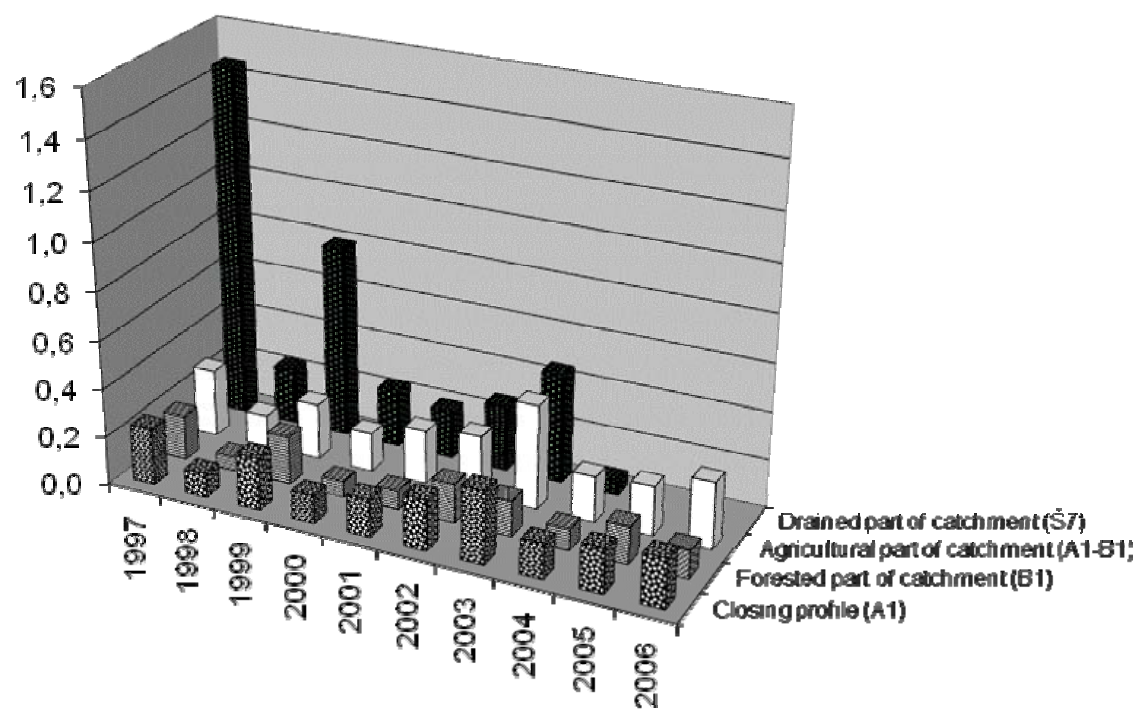

Fig. 3. Mean annual runoff coefficient for individual sections of the Cerhovice stream catchment (1997-2006)

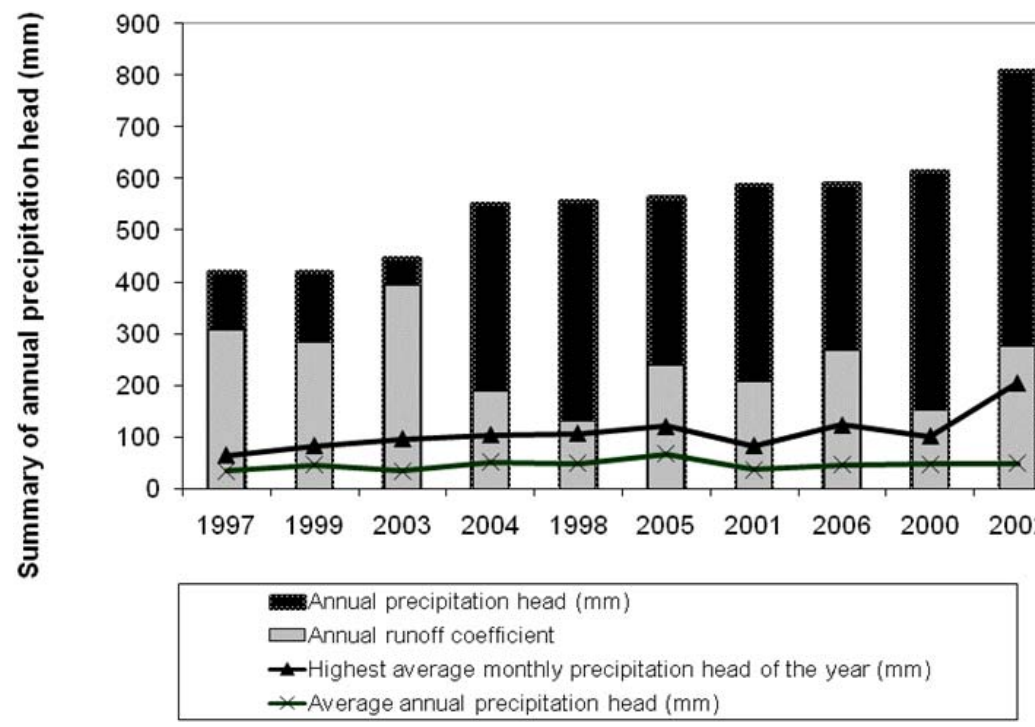

Fig. 4. The interdependence between annual runoff coefficient and incidence of precipitation

There is an unstable correlation between precipitation and runoff visible on the previous graph. In this graph we chose two years with the highest and lowest mean annual runoff coefficient (2003 and 1998) to consider revising their monthly precipitation and runoff. The exact data are in Table 6. 
Table 6. Monthly precipitation and the runoffs in the end profile A1 (1998 and 2003)

\begin{tabular}{l|c|c|c|c}
\hline \multirow{2}{*}{ Month } & \multicolumn{2}{c|}{ Year 1998 } & \multicolumn{2}{c}{ Year 2003 } \\
\cline { 2 - 5 } & precipitation, $\mathrm{mm}$ & runoff, $\mathrm{mm}$ & precipitation, $\mathrm{mm}$ & runoff, mm \\
\hline November & 33.5 & 1.9527 & 71.6 & 39.7707 \\
December & 24.4 & 3.3554 & 11.8 & 21.1036 \\
January & 12.9 & 1.7007 & 35.9 & 27.7897 \\
February & 10.5 & 2.3324 & 17.9 & 8.3277 \\
March & 38.3 & 7.6946 & 11.2 & 14.7558 \\
April & 16.3 & 2.8447 & 19.78 & 5.5534 \\
May & 11.8 & 1.2744 & 41.8 & 5.7730 \\
June & 106.7 & 6.9767 & 79.3 & 5.4140 \\
July & 93.9 & 8.2286 & 95.7 & 4.1608 \\
August & 33.6 & 1.1288 & 9.9 & 1.1040 \\
September & 84.2 & 5.9206 & 14.1 & 0.6718 \\
October & 89.7 & 13.2417 & 35.4 & 1.9761 \\
\hline
\end{tabular}

Fig. 5 clearly indicates the precipitation - runoff interdependence at the closing end profile A1 between 1998 and 2003; monthly precipitation and runoff are evaluated through double summary line, summarization is made in chronological sequence.

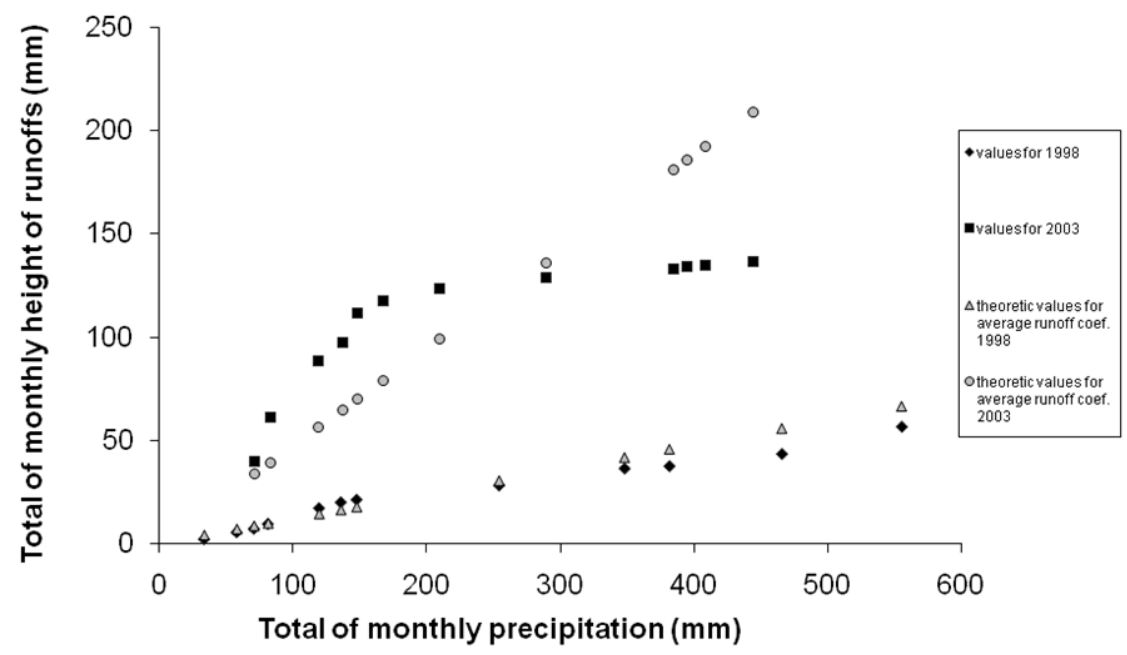

Fig. 5. The double summary precipitation and runoff line (evaluated acc. to BuDík and BuDíKOVÁ (2001))

For better understanding of the high runoffs in the beginning of hydrological year 2003 we made another chart with runoffs and precipitation of the previous three month in 2002 (Tab. 7). 
Table 7. Monthly precipitation and runoff during the months of 2002 with extreme precipitation

\begin{tabular}{l|c|c}
\hline \multirow{2}{*}{ Month } & \multicolumn{2}{c}{ Year 2002 } \\
\cline { 2 - 3 } & precipitation, mm & runoff, $\mathrm{mm}$ \\
\hline August & 205.20 & 67.68 \\
September & 57.60 & 5.74 \\
October & 64.45 & 12.56 \\
\hline
\end{tabular}

\section{DISCUSSION}

Figure 2 evidently shows the smaller contribution of the forest lands to the runoff within the end profile. It also demonstrates ambiguous interdependencies of the runoff on precipitation. In Figure 3 it is also visible that the values for drainage section of the catchment (chamber S7) are usually higher than those for the profile A1. Moreover, the value for 1996 and 1997 reaches one, which is also evident from Fig. 2. The higher total flow could indicate the presence of water springs within a given catchment locality; that might be connected with detection of underground water. The hydro station situated in the northeast part of the locality documents this. The highway construction was also finalised during the study years, which could also be connected with the unstable runoff.

In Table 3 we grouped the mean runoffs' values from various sections of the experimental catchment into proper time periods. The runoff coefficient for the farmland following the completion of the highway construction seems to be lower, which is also supported by the standard deviations given in Table 3. Statistical tests did not confirm this conclusion.

Similarly, the total runoff coefficient at the end profile during the years of highway construction seemed to be lower but it wasn't also confirmed by statistical calculations. Possible reason for the lowering of the runoff coefficient during the years after the highway building could be the reduction of the experimental catchment's area. Another reason could be the disturbance of some runs driving the water to the end profile. Lowering of the runoff coefficient was demonstrated by SOUKUP et al. (2006).

Using runoff coefficients from the end profile, we also compared the period prior to, and the period after the completion of the super warehouse construction. Due to the short term of measurements it cannot be concluded that the runoff coefficient have increased. Convincing confirmation of the increased runoff could mean the lowering of soil permeability within the given section of the catchment.

When comparing the drier and wetter years (Tab. 5), the runoff coefficient seems to be higher for wetter years prior to construction, whereas for the period after highway construction the same coefficient, paradoxically, is higher for the drier period. None of these conclusions was confirmed by the statistics. 


\section{The mean volume runoff coefficient for the Cerhovice Stream catchment} then is 0.1903 and it is taken from the period after the highway building. Standard deviation of the value for the study period is 0.0611 .

Further we looked for the possible reason of the quite high value of standard deviation and also of the mentioned ambiguous relationships between runoff and precipitation from Fig. 3. To evaluate precipitation - runoff relationships we have drafted Fig. 4 in which the equivocation of this relationship is visible over the study period. According to this particular graph we selected the years 2003 and 1998 as the years with the highest and the lowest runoff coefficients and with disproportionate runoff - precipitation relations. To record these two years we have drafted Tab. 5 and the graph of a dual total line for monthly precipitation and the runoff (Fig. 5). In the table one can see monthly precipitation and runoff during the study period; there are disproportional reactions of the runoff to precipitation visible in this graph especially for the first part of the hydrological year 2003. These disproportional reactions are also visible in Fig. 5, where the first half of the year 2003 has steeper course of the curve than the same part of the curve for the year 1998. There are also theoretical double summary lines for mean runoff coefficients for both years in the graph. By comparing the theoretical and measured values we can also see how the mean values are sometimes far away from the real ones.

Higher runoff in the beginning of the year 2003 could be caused by water saturation of the soil because of previous floods in 2002. Other reasons could be the runoffs related to precipitations of the previous period, possible presence of the underground springs and lower permeability caused for example by the frozen soil. The values of precipitation and runoff in the months of extreme precipitation in 2002 are shown in Tab. 7. Due to this precipitation, the runoff in early months of 2003 was still higher than that accompanying extreme precipitation in 2002. For deeper understanding of this fact we followed a possible relationship between runoff coefficients and ground water table depths (Fig. 6). As seen in the graph, the relationship is very weak. Simultaneously, we analysed the relationship between the runoff coefficient and water temperature (Fig. 7). For more exact conclusion we should observe longer time series, nevertheless the value of $R^{2}=0.6667$ for runoff coefficient regressed on water temperature is significant. More data measured in different localities are needed to explain the reasons and consequences of observed relations. For example, we did not evaluate the effect of forest management.

\section{CONCLUSIONS}

This contribution based on over a ten-year long study estimated the mean annual runoff coefficient of the Cerhovice Stream catchment at 0.19 with the standard deviation of 0.06 . We also compared the runoff coefficients in forested, agricul- 


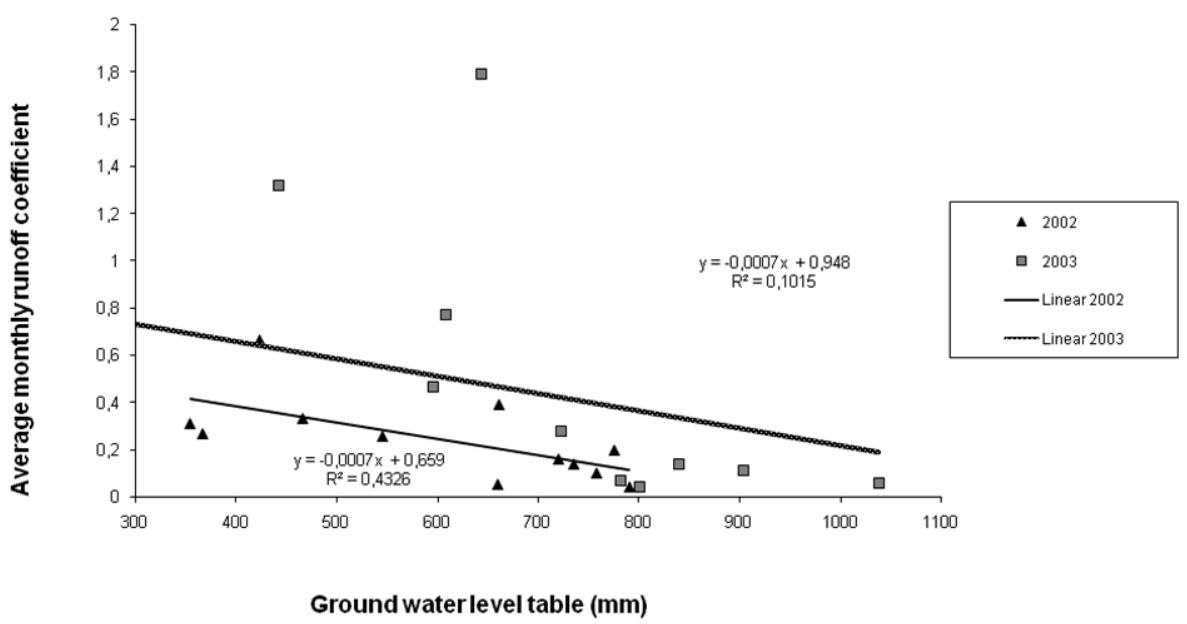

Fig. 6. Runoff dependence on high of groundwater level in 2002 and 2003

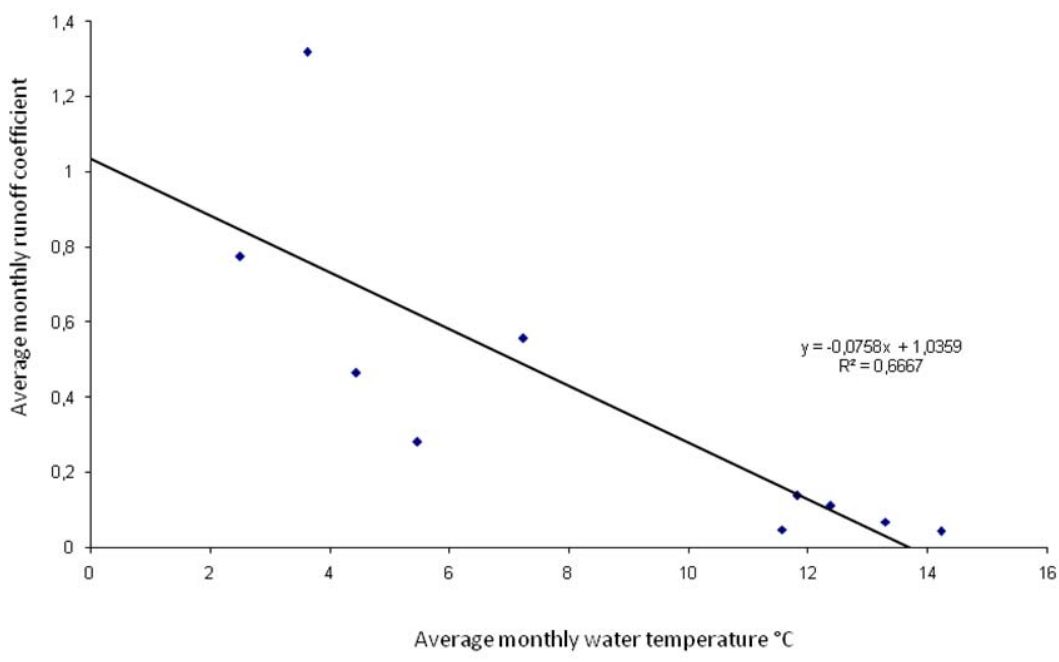

Fig. 7. Runoff coefficient dependence on water temperatures - the Cerhovice stream; hydrological year 2003

tural and drained sections of the experimental catchment. Agricultural part of the catchment contributed most to the total runoff from the catchment.

We also differentiated the data for individual periods; the one prior to the highway and super warehouse construction and the period after the two projects were completed. The runoff coefficient values for drier and wetter years from our ten-year long study were also compared. The evaluation showed that changes of the land use in some parts of the catchment did not evoke any statistically signifi- 
cant changes in the runoff ratio. There were also no significant differences between the dryer and wetter periods.

Further we used two lines of evidence to explain a high standard deviation of the mean runoff coefficient. The first one - runoff coefficient dependence on ground water level was not significant. The second one - the dependence of mean monthly runoff coefficient on water temperature was highly significant with the correlation coefficient of 0.67 .

For a more accurate evaluation of this case, a larger dataset will be needed.

\section{Acknowledgement}

This study is presented within the intentional project MZE002704901 Minimizing of the Negative Natural and Anthropogenic Influences on Fertile Earth and Water.

\section{REFERENCES}

1. BudíK R., BudíKOvÁ M., 2001. Statistically processed monthly and yearly precipitation and runoff characteristics within Morava River Watershed. Works and Studies, folder 28. Prague, Czech Hydrometeorol. Inst.: 118.

2. BerANKIENE L., 2002. The perennial change of precipitation and annual runoff in the Susve river basin. Transactions of the Water Management Institute of Lithuanian University of Agriculture, 20 (42).

3. DOLEŽAL F., 2002. Experimental agro-forest catchment VÚMOP within Central Bohemian crystalline formation. Summary Report from Nové Hrady Workshop, 16. October 2001. VÚMOP Prague, Prague 2002, P. 16 (96).

4. Doležal F., KulhavÝ Z., KvítKe T., Soukup M., ČMelík M., Fučík P., NovÁk P., Peterková J., PilnÁ E., PraŽÁK P., TipPl M., UhlířovÁ J., ZAVAdil J., 2006. Hydrological research of small agricultural catchments. J. Hydrol. Hydromech., 54, 2: 217-229.

5. DostÁl T., 2002. Lecture on flood protection, ČVUT Chair of Hydro-meliorations and Landmass Engineering: http://storm.fsv.cvut.cz/on_line/zp50/pr_12.ppt\#294,11,Figure 11

6. HRÁDEK F., KuŘí P., 2004. Hydrologie. Prague, Česká zemědělská univerzita v Praze: 271.

7. JANEČEK M. et al., 2002. Protection of farmland against erosion. First edition. Prague, ISV Publishers: 201.

8. KÁBA B., SvatoŠová L., 1988. Statistika. Praha, Vysoká škola zemědělská: 94.

9. KAdioglu M., ŞEN Z., 2001. Monthly precipitation-runoff polygons and mean runoff coefficients. Hydrological Sciences-Journal-des Sciences Hydrologiques, 46 (1): 3-11.

10. MAIDMENT D.R., 1993. Handbook of hydrology. New York USA, McGraw-Hill: 1424.

11. MAXOvÁ M., SOUKUP M., 2004. Evaluation of specific hydrological figures of two experimental catchments in 2002 with emphasis on August flood. Soil and Water 3/2004. Prague, VÚMOP: 133.

12. RAtZlAfF J.R., 1994. Mean annual precipitation, runoff, and runoff ratio for Kansas, 1971-1990. Trans. Kansas Acad. Sci., 97 (3-4): 94-101.

13. SAVENIJE H.G., 1995. The runoff coefficient as the key to moisture recycling. J. Hydrol., 176: 219225.

14. SouKuP M., 1987. Analysis of drainage influence on certain characteristics of the runoff in Cidlina River catchment section. Scientific Works VÚZZP 5, Prague.

15. SOUKuP M. et al., 2000. Runoff regulation and retardation within an agricultural catchment. Annual report for 1999, project EP 090006150 NAZV 11 Countryside Water Management and the Protection of Hydrosphere. Prague, VÚMOP: 32. 
16. Soukup M., Kulhavý Z., Pilná E., Maxová J., Eichler J., Hospodka P., Doležal F., Čmelík M., JoHANOVSKÝ Z., 2003. The effect of controlled melioration intrusions on hydrological regimes of various loam types and hydrological processes in the countryside. 2002 Ann. Report VÚMOP Prague: $29+$ appendix.

17. SouKuP M., NeChVÁtal M., 2006. Influence of extensive structures on runoff within agricultural and forest Cerhovice Stream catchment. Water Manag., 8 Prague: 285.

18. Soukup M., NechVÁtal M., Pilná E., 2006. Drainage outflow from the sporadic and field drainage from the agricultural and forest catchment of the Cerhovický Stream. Adolf Patera Workshop 2006. CVUT, Praha: 125.

19. Soukup M., Maxová J., Pilná E., 2004. Drainage runoff at Cerhovice Stream during dry period in 2003. In the collection of extreme hydrological phenomena within catchments. Adolf Patera Workshop. ČVUT a ČVVS, Prague: 63-70.

20. ŠviHLA V., 1979. Research of runoff conditions within a small catchment. Task within Timeframe Report. Prague, Melior. Res. Inst.: 168.

21. Global Runoff Data Centre (GRDC), 2004: GRDC Runoff coefficient estimate in \%: http:/grdc. bafg.de/servlet/is/7075/

22. Voda v České Republice: http://www.zemepis.com/vodacr.php

\section{STRESZCZENIE}

\section{Roczny współczynnik spływu w zlewni strumienia Cerhovickiego}

Słowa kluczowe: poziom wód gruntowych, rok mokry, rok suchy, temperatura wody, użytkowanie ziemi, wspótczynnik spływu

Współczynnik spływu jest jedną z podstawowych cech hydrologicznych zlewni. Określa on tę część wód opadowych, która odpływa ze zlewni. W pracy przedstawiono wyniki obliczeń współczynnika spływu na podstawie ciagłych i długotrwałych (1988-2006) pomiarów opadu i spływu, prowadzonych w zlewni strumienia Cerhovickiego. Podano średni współczynnik spływu dla zlewni i oddzielnie dla jej czesści rolniczej i zalesionej. Średni współczynnik dla zlewni wynosił 0,19 z odchyleniem standardowym 0,06 . Średnie współczynniki spływu dla części zalesionej i użytkowanej rolniczo wynosiły odpowiednio 0,13 i 0,24 .

Analizowano także różnice między latami o większych i mniejszych opadach atmosferycznych. Statystycznie oceniono również możliwe zmiany hydrologiczne spowodowane budową autostrady i centrum handlowego. Aby wyjaśnić względnie wysokie odchylenie standardowe od średniego rocznego współczynnika spływu, zbadano zależność miesięcznych wartości współczynnika od temperatury wody i poziomu zwierciadła wód gruntowych.

Received 05.11.2008

Reviewers:

Prof. Andrzej Ciepielowski

Dr Tomasz Szymczak 